\title{
COMMENTARY
}

\section{C9orf72 immunohistochemistry in Alzheimer's disease}

Tibor Hortobágyi $i^{* 1,2}$

See related research by Satoh et al., http://alzres.com/content/4/4/33
Chromosome 9 open reading frame $72(\mathrm{C} 90 \mathrm{ff} 72)$ is a protein with unknown function and a high level of expression in the brain and spinal cord. The discovery of expanded heptanucleotide repeat mutations as the most common genetic cause of familial and sporadic frontotemporal dementia (FTD) and amyotrophic lateral sclerosis (ALS) [1,2] provided further evidence for a phenotypic spectrum with overlapping genetic [3-5], pathological $[6,7]$, and clinical $[8,9]$ features. C9orf72 mutant FTD and ALS (C9FTD/ALS) cases reveal a characteristic neuropathological signature with abundant p62-positive inclusions in the hippocampus and cerebellum [6,7] and a unique pattern of ubiquilin pathology [10]. C9orf72 repeat expansion mutation in large cohorts of patients with $\mathrm{AD}$ has been either absent [11] or identified exceedingly rarely [12].

In the previous issue of Alzheimer's Research \& Therapy, Satoh and colleagues [13] present an analysis of C9orf72 expression and its relation to ubiquitin, p62, and

\footnotetext{
*Correspondence: hortobagyi@med.unideb.hu

'Department of Neuropathology, Institute of Pathology, Medical and Health

Science Centre, University of Debrecen, 4032 Debrecen, Nagyerdei krt. $98 .$,

Hungary

Full list of author information is available at the end of the article
}

ubiquilin-1, ubiquilin-2 immunoreactivity in control, Alzheimer's disease (AD), sporadic ALS, Parkinson's disease, and multiple system atrophy brains. Early studies have consistently shown that C9orf72 is negative in intracellular inclusions including tau-positive structures except for Pick bodies (for references, see [13]). In contrast to these previous studies, Satoh and colleagues report C9orf72 in a subset of dystrophic neurites in AD. Another major finding is the demonstration of C9orf72 and ubiquilin-1 positivity in a cluster of dystrophic neurites in senile plaques in $\mathrm{AD}$ brains by using antibodies discriminating ubiquilin-1 from ubiquilin-2; these results warrant further studies into the role of ubiquilin in neurodegeneration. The thorough analysis of two different anti-C9orf72 antibodies for the pattern of immunoreactivity, specificity, cross-reactivities is an important aspect of the study. The results suggest that the testing of further antibodies available on the market and the generation of novel highly specific anti-C9orf72 antibodies are necessary to facilitate research into neurodegenerative diseases, in particular C9FTD/ALS. Unfortunately, C9orf72 mutation status has not been analyzed in the included cases either; Satoh and colleagues assume that cases are likely to be negative in view of the low prevalence of C9orf72 mutation in ALS and FTD in Japanese patients [14] in comparison with Caucasian patients [15]. Pathological proteins incorporated into characteristic inclusions in neurodegenerative diseases are rather detergent-insoluble; the analysis of this key feature is still awaited. The case numbers are low in this study. Therefore, as the authors themselves have suggested, further studies are needed to test the presented findings in larger cohorts and by more detailed analysis. This paper provides a nidus around which the presented observations can be more robustly studied and clarified.

\section{Abbreviations}

AD, Alzheimer's disease; ALS, amyotrophic lateral sclerosis; C9FTD/ALS, frontotemporal dementia or amyotrophic lateral sclerosis (or both) linked to chromosome 9; C9orf72, chromosome 9 open reading frame 72; FTD, frontotemporal dementia.

\section{Competing interests}

The author declares that he has no competing interests. 


\section{Author details}

'Department of Neuropathology, Institute of Pathology, Medical and Health Science Centre, University of Debrecen, 4032 Debrecen, Nagyerdei krt. 98., Hungary. ${ }^{2}$ Department of Clinical Neuroscience, Institute of Psychiatry, King's College London, De Crespigny Park, London, SE5 8AF, UK.

Published: 26 September 2012

\section{References}

1. DeJesus-Hernandez M, Mackenzie IR, Boeve BF, Boxer AL, Baker M, Rutherford NJ, Nicholson AM, Finch NA, Flynn H, Adamson J, Kouri N, Wojtas A, Sengdy P, Hsiung GY, Karydas A, Seeley WW, Josephs KA, Coppola G, Geschwind DH, Wszolek ZK, Feldman H, Knopman DS, Petersen RC, Miller BL, Dickson DW, Boylan KB, Graff-Radford NR, Rademakers R: Expanded GGGGCC hexanucleotide repeat in noncoding region of C9ORF72 causes chromosome 9p-linked FTD and ALS. Neuron 2011, 72:245-256.

2. Renton AE, Majounie E, Waite A, Simón-Sánchez J, Rollinson S, Gibbs JR, Schymick JC, Laaksovirta H, van Swieten JC, Myllykangas L, Kalimo H, Paetau A, Abramzon Y, Remes AM, Kaganovich A, Scholz SW, Duckworth J, Ding J, Harmer DW, Hernandez DG, Johnson JO, Mok K, Ryten M, Trabzuni D, Guerreiro RJ, Orrell RW, Neal J, Murray A, Pearson J, Jansen IE, et al.: A hexanucleotide repeat expansion in C9ORF72 is the cause of chromosome 9p21-linked ALS-FTD. Neuron 2011, 72:257-268.

3. Schymick JC, Traynor BJ: Expanding the genetics of amyotrophic lateral sclerosis and frontotemporal dementia. Alzheimers Res Ther 2012, 4:30.

4. Al-Chalabi A, Jones A, Troakes C, King A, Al-Sarraj S, van den Berg LH: The genetics and neuropathology of amyotrophic lateral sclerosis. Acta Neuropathol 2012, 124:339-352.

5. Sieben A, Van Langenhove T, Engelborghs S, Martin JJ, Boon P, Cras P, De Deyn PP, Santens P, Van Broeckhoven C, Cruts M: The genetics and neuropathology of frontotemporal lobar degeneration. Acta Neuropathol 2012, 124:353-372.

6. Al-Sarraj S, King A, Troakes C, Smith B, Maekawa S, Bodi I, Rogelj B, Al-Chalabi A, Hortobágyi T, Shaw CE: p62 positive, TDP-43 negative, neuronal cytoplasmic and intranuclear inclusions in the cerebellum and hippocampus define the pathology of C9orf72-linked FTLD and MND/ ALS. Acta Neuropathol 2011, 122:691-702.

7. Murray ME, DeJesus-Hernandez M, Rutherford NJ, Baker M, Duara R, GraffRadford NR, Wszolek ZK, Ferman TJ, Josephs KA, Boylan KB, Rademakers R, Dickson DW: Clinical and neuropathologic heterogeneity of c9FTD/ALS associated with hexanucleotide repeat expansion in C9ORF72. Acta Neuropathol 2011, 122:673-690.

8. Boeve BF, Graff-Radford NR: Cognitive and behavioral features of C9FTD/ ALS. Alzheimers Res Ther 2012, 4:29.
9. Troakes C, Maekawa S, Wijesekera L, Rogelj B, Siklós L, Bell C, Smith B, Newhouse S, Vance C, Johnson L, Hortobágyi T, Shatunov A, Al-Chalabi A, Leigh N,Shaw CE, King A, Al-Sarraj S: An MND/ALS phenotype associated with C9orf72 repeat expansion: Abundant p62-positive, TDP-43-negative inclusions in cerebral cortex, hippocampus and cerebellum but without associated cognitive decline. Neuropathology 2011 Dec 19 [Epub ahead of print].

10. Brettschneider J, Van Deerlin VM, Robinson JL, Kwong L, Lee EB, Ali YO, Safren N, Monteiro MJ, Toledo JB, Elman L, McCluskey L, Irwin DJ, Grossman M,Molina-Porcel L, Lee VM, Trojanowski JQ: Pattern of ubiquilin pathology in ALS and FTLD indicates presence of C9ORF72 hexanucleotide expansion. Acta Neuropathol 2012, 123:825-839.

11. Rollinson S, Halliwell N, Young K, Callister JB, Toulson G, Gibbons L, Davidson YS, Robinson AC, Gerhard A, Richardson A, Neary D, Snowden J, Mann DM, Pickering-Brown SM: Analysis of the hexanucleotide repeat in C9ORF72 in Alzheimer's disease. Neurobiol Aging 2012, 33:1846 e5-6.

12. Majounie E, Abramzon Y, Renton AE, Perry R, Bassett SS, Pletnikova O, Troncoso JC, Hardy J, Singleton AB, Traynor BJ: Repeat expansion in C9ORF72 in Alzheimer's disease. N Engl J Med 2012, 366:283-284.

13. Satoh Jl, Tabunoki H, Ishida T, Saito Y, Arima K: Dystrophic neurites express C9orf72 in Alzheimer's disease brains. Alzheimers Res Ther 2012, 4:33.

14. Ogaki K, Li Y, Atsuta N, Tomiyama H, Funayama M, Watanabe H, Nakamura R, Yoshino H, Yato S, Tamura A, Naito Y, Taniguchi A, Fujita K, Izumi Y, Kaji R, Hattori N, Sobue G; Japanese Consortium for Amyotrophic Lateral Sclerosis research (JaCALS): Analysis of C9orf72 repeat expansion in 563 Japanese patients with amyotrophic lateral sclerosis. Neurobiol Aging 2012, 33:2527. e11-6.

15. Smith BN, Newhouse S, Shatunov A, Vance C, Topp S, Johnson L, Miller J, Lee Y, Troakes C, Scott KM, Jones A, Gray I, Wright J, Hortobágyi T, Al-Sarraj S, Rogelj B, Powell J, Lupton M, Lovestone S, Sapp PC, Weber M, Nestor PJ, Schelhaas HJ, Asbroek AA, Silani V, Gellera C, Taroni F, Ticozzi N, Van den Berg L,Veldink J, et al:: The C9ORF72 expansion mutation is a common cause of ALS+/-FTD in Europe and has a single founder. Eur J Hum Genet 2012 Jun 13 [Epub ahead of print]

doi:10.1186/alzrt140

Cite this article as: Hortobágyi T: C9orf72 immunohistochemistry in Alzheimer's disease. Alzheimer's Research \& Therapy 2012, 4:37. 